\title{
ВMJ Global Health Equity without human rights: a false COVID-19 narrative?
}

To cite: Khosla R, Gruskin S Equity without human rights: a false COVID-19 narrative?BMJ Global Health 2021;6:e006720. doi:10.1136/ bmjgh-2021-006720

Received 24 June 2021 Accepted 29 June 202

Check for updates

C) Author(s) (or their employer(s)) 2021. Re-use permitted under CC BY-NC. No commercial re-use. See rights and permissions. Published by BMJ.

${ }^{1}$ Amnesty International, London, UK

${ }^{2}$ Institute on Inequalities in Global Health, University of Southern California, Los Angeles, California, USA

Correspondence to Professor Sofia Gruskin Gruskin@med.usc.edu
As of 24 June, about $22.35 \%$ of the world population have been vaccinated against COVID-19. This represents a range from a low of $2.48 \%$ in Africa to a high of $39.01 \%$ in Europe and $41.43 \%$ in North America. ${ }^{1}$ Many have lamented the need to address these gaps and have vociferously called for ensuring vaccine equity. The question must be asked: if the goal is for all people to be vaccinated, will equity alone get us there?

Over and above simply the availability of vaccine a multitude of factors have been identified as contributing to gaps in vaccination rates, ranging from individual hesitancy, to community distrust, to inadequate national health systems, let alone global-level supply chain issues and restrictive intellectual property regimes. While not unique to COVID-19, many of these have proven even more nefarious in the context of access to COVID-19 vaccine, with implications for global health more broadly. An equity approach is certainly needed to bring attention to such injustice, but learnings from HIV and other areas of health have demonstrated the utility of attention to human rights norms and standards, and that the rule of law and accountability are key components of what is needed to truly make the difference. The last decades have shown time and again the value of human rights not only for advocacy purposes but also to provide sustained, long-term solutions. Therefore, we posit that an equity-oriented approach systematically combined with human rights may help not only to address the present vaccine crisis but to address inequalities in global health more broadly.

As far back as 2003, Braveman et $a l^{2}$ pointed out that the relationships between health, equity and human rights had not been examined rigorously. These concepts have sometimes been viewed as conflicting or competing, and as a consequence depending on the champion, one or the other often considered irrelevant. ${ }^{2}$ Unfortunately it seems this still holds true today.
Many in the global health community call for 'equity' as key to addressing the COVID-19 crisis, with little concrete articulation as to what this can mean in practice-and with even less attention to what human rights can offer to equity concerns. Even the Independent Panel for Pandemic Preparedness and Response in its final report ${ }^{3}$ and the World Health Assembly resolution on pandemic preparedness ${ }^{4}$ did not go beyond cursory or preambular references to human rights, alongside several largely rhetorical references to equity. ${ }^{4}$ And so the question must be asked. Is this due to a genuine lack of understanding of what these concepts bring or rather a lack of political will and resistance from those in power to the concrete results human rights would require. It could not be the former, as the panel itself commissioned a well-circulated paper $^{5}$ laying out these concepts, which unfortunately failed to get adequately reflected in the final report or the resolution. One is therefore forced to conclude that these processes were bogged down by the political pressures from member states, many of whom find equity more politically palatable. This also supports a narrative that continues to play equity versus human rights, whereby equity is presented as the more acceptable, palatable option to dominant ideologies and national politics. The end result here, and in much of global health, is a lowest common denominator approach which does not help deliver the ultimate objective of health for all.

This is not to say that a framing on equity is not needed. It very much is. Equity is an ethical concept grounded in the principle of distributive justice. ${ }^{2}$ WHO defines equity as "the absence of avoidable or remediable differences among groups of people, whether those groups are defined socially, economically, demographically, or geographically'. In operational terms "pursuing equity in health means eliminating health disparities that are systematically associated with 
underlying social disadvantage or marginalization'. ${ }^{2}$ But who decides what is equitable? And according to what criteria?

So what do human rights offer? Equity in approach is needed ultimately to achieve equality in result. Healthcare in the event of sickness for all people, as well as the prevention, treatment and control of diseases, are central features of the right to the highest attainable standard of health as recognised in the International Covenant on Economic, Social and Cultural Rights which has over 170 States Parties. In recent years, WHO, the United Nations Committee on Economic, Social and Cultural Rights, the United Nations Special Rapporteur on the Right to Health, civil society organisations, academics and many others have provided guidance on operationalising the right to health.

The key elements of this approach include an emphasis on the implementation of relevant national and international human rights laws, norms and standards as underlying a country's legal obligations, not as matters of goodwill or philanthropy but of law; recognition that obligations such as those to ensure equality and non-discrimination are subject to neither resource constraints nor progressive realisation, but are of immediate effect. Applied to this context, while realisable over time, this would mean countries have an obligation to avoid discrimination of any sort in access to COVID-19 vaccines and are accountable for their actions. ${ }^{7}$ In the context of vaccine distribution, particularly relevant also is the international human rights law tenet that speaks to the obligations of nation states beyond their borders, that is, to their responsibilities to international assistance and cooperation, akin to their domestic obligations, not subsidiary or secondary in any way. ${ }^{8}$

Critically adopting human rights, alongside an equity framework, provides an opportunity for the active and informed participation of individuals and communities in many ways useful to supporting vaccine distribution and uptake amongst all populations. Individuals and communities must be considered as active agents/participants in decision-making rather than simply passive beneficiaries. And importantly, human rights bring to the fore effective, transparent and accessible monitoring and accountability mechanisms available at the national and international levels to ensure that there are remedy and redress mechanisms available to address any violations occuring as vaccine roll-out continues.

Human rights are fundamental to achieving health equity for all. As the experience of the COVID-19 pandemic continues to demonstrate, human rights violations lie at the heart of failures which led to the inadequacy of access to testing, to personal protective equipment and to vaccines, but also in the approaches taken to preventing infection, including not only the use but also the misuse of legal response measures which brought these stark inequalities to the fore. As Yamin and Farmer ${ }^{9}$ have recently pointed out there is an urgent need to "challenge the opaque mechanisms through which global health agendas are set and to interrogate how 'truth' and 'knowledge' are constructed in global health".[9] Time is now to challenge these constructs and step away from an equity versus rights approach and embrace a more holistic approach to global health, one which fosters a deeper, meaningful integration of equity and human rights approaches and that can help us to recover as a more just and vaccinated society-no matter who we are or where we live.

Contributors RK and SG conceived of the commentary. RK developed the first draft and SG reviewed and critically edited the manuscript. RK and SG finalised the manuscript jointly.

Funding The authors have not declared a specific grant for this research from any funding agency in the public, commercial or not-for-profit sectors.

Competing interests None declared.

Patient consent for publication Not required.

Provenance and peer review Not commissioned; internally peer reviewed.

Data availability statement Data sharing is not applicable to this article as no datasets were generated or analysed during the current study.

Open access This is an open access article distributed in accordance with the Creative Commons Attribution Non Commercial (CC BY-NC 4.0) license, which permits others to distribute, remix, adapt, build upon this work non-commercially, and license their derivative works on different terms, provided the original work is properly cited, appropriate credit is given, any changes made indicated, and the use is non-commercial. See: http://creativecommons.org/licenses/by-nc/4.0/.

\section{REFERENCES}

1 ourworldindata.org. Data extracted from ourworldindata.org, 2021. Available: https://ourworldindata.org/ [Accessed 24 Jun 2021].

2 Braveman P, Gruskin S, Poverty GS. Poverty, equity, human rights and health. Bull World Health Organ 2003;81:539-45.

3 The independent panel. COVID-19 make it the last pandemic, 2021. Available: https://theindependentpanel.org/mainreport/

4 WHA. Strengthening WHO preparedness for and response to health emergencies, 2021. Available: https://apps.who.int/gb/ebwha/pdf_ files/WHA74/A74_ACONF2-en.pdf

5 Mesquita JBde, Kapilashrami A, Meier BM. Human rights dimensions of the COVID-19 pandemic., 2020. Available: https:// theindependentpanel.org/wp-content/uploads/2021/05/Backgroundpaper-11-Human-rights.pdf

6 WHO. Available: https://www.who.int/healthsystems/topics/equity/en/ [Accessed Jun 2021].

7 Hunt P, Khosla R. The Human Right to Medicines. Sur Vol 5 (no8), 2008. Available: https://sur.conectas.org/wp-content/uploads/2017/ 11/sur8-eng-paul-hunt-and-rajat-khosla.pdf

8 WHO. Addressing human rights in COVID-19 response, 2020. Available: https://www.who.int/publications/i/item/addressing-humanrights-as-key-to-the-covid-19-response

9 Yamin A, Farmer P. Against nihilism: transformative human rights praxis for the future of global health. OpenGlobalRights, 2021. Available: https://www.openglobalrights.org/against-nihilismtransformative-human-rights-praxis-for-the-future-of-global-health/ [Accessed Jun 2021]. 